\section{Я.Ю. ДАНИЛОВА}

Уфимский государственный институт искусств имени Загира Исмагилова Лаборатория музыкальной семантики 2. Уфа, Россия lab234nt@yandex.ru

\section{YANA YU. DANILOVA}

Ufa State Institute of Arts named after Zagir Ismagilov Laboratory of Musical Semantics

Ufa, Russia

lab234nt@yandex.ru

\section{Атрибутивные признаки героев и персонажей комической оперы в тематизме фортепианных сонат В.А. Моцарта}

Многие инструментальные сочинения композиторов XVII-XVIII веков основаны, как известно, на принципе театрализации сюжета, который воплощает героев и персонажей оперных сочинений, а также различные «кочующие сюжеты», драматические и комические ситуации, зародившиеся в театральных и оперных произведениях. В фортепианных сонатах Моцарта часто можно обнаружить музыкальное воплощение типичных признаков образов-характеров, а также связанных с ними кочующих комических оперных ситуаций. Такой тип сюжетной организации клавирного текста можно назвать театральным.

Статья посвящена анализу признаков кочующих оперных героев и персонажей, мизансцен, сцен-монологов, диалогов и полилогов, а иногда и целых действий, состоящих из нескольких сменяющихся сцен, где возникает семантическая ситуация «текст в тексте». В клавирном сочинении она воплощается в форме театрального диалога, в котором явно присутствуют признаки речевых актов и двигательной пластики.

\section{Ключевые слова:}

Моцарт, клавирные сонаты, образы комических опер, театральный диалог в сонате.

\section{Attributive Indications of Characters and Protagonists of Comic Operas in the Thematicism of Mozart's Clavier Sonatas}

Many instrumental works by 17 th and 18th century composers are generated, as it is well known, on the principle of the atricalization of the plots which demonstrates the characters and protagonists of opera works, various "migrating plotlines," dramatic and comic situations generated in theatrical and opera works. In Mozart's clavier sonatas it frequently becomes possible to discern the musical manifestation of typical indications of characteristic images, as well as the migrating comic opera attributes connected with them. This type of plotline organization of the piano musical text may be labeled as theatrical.

The article is aimed at analyzing the signs of migrating operatic characters and protagonists, stage settings, dialogues and polylogues, and at times entire theatrical acts, consisting of several alternating scenes demonstrating the appearance of the semantic situation of "a text within a text." Within the scope of a clavier composition this manifests itself in the form of a theatrical dialogue containing signs of verbal actions and motional plastic arts.

\section{Keywords:}

Mozart, clavier sonatas, images of comic operas, theatrical dialogue in a sonata. 
Для цитирования/For citation:

Данилова Я.Ю. Атрибутивные признаки героев и персонажей комической оперы в тематизме фортепианных сонат В. А. Моцарта // ИКОНИ / ICONI. 2020. № 1. С. 30-40. DOI: $10.33779 / 2658-4824.2020 .1 .030-040$.

$\mathrm{M}$ ногие инструментальные сочинения композиторов XVII-XVIII веков основаны, как известно, на принципе театрализации сюжета, который воплощает героев и персонажей оперных сочинений, а также различные «кочующие сюжеты», драматические и комические ситуации, зародившиеся в театральных и оперных произведениях. В фортепианных сонатах Моцарта часто можно обнаружить музыкальное воплощение типичных признаков образов-характеров, а также связанных с ними кочующих комических оперных ситуаций. Такой тип сюжетной организации клавирного текста можно назвать театральным.

Благодаря проникновению в содержание сонат признаков кочующих оперных героев и персонажей, мизансцен, сцен-монологов, диалогов и полилогов, а иногда и целых действий, состоящих из нескольких сменяющихся сцен, возникает семантическая ситуация «текст в тексте». В клавирном сочинении она воплощается в форме театрального диалога, в котором явно присутствуют признаки речевых актов и двигательной пластики.

Интонационно-лексический строй многих музыкальных произведений часто, как отмечают исследователи, носит антропоморфный характер. Репрезентация героя в тексте клавирного сочинения происходит посредством атрибутивны $x^{1}$ признаков, которые концентрируют в себе гендерные, социальные, эмотивноречевые и психомоторные поведенческие черты того или иного индивида. Атрибутирование (P.М. Байкиева) образов-характеров часто выражается в лек- сике эмотивно-речевого (вдох, вопрос, восклицание, утверждение, междометие, выкрик и т. д.) и двигательно-пластического (приседание, поклон, шаги, бег и др.) происхождения.

Как показали наблюдения, в клавирных сонатах Моцарта встречаются группы женских и мужских образовхарактеров, в каждой из которых по социальной принадлежности противопоставлены пары по типу Графиня - Служанка, Граф - Слуга. Все они содержат определённый комплекс музыкально-лексических атрибутивных признаков, которые выявляются в их репликах, где вне зависимости от ситуативного контекста показаны свойственные им «façon de parler» ${ }^{2}$, двигательная пластика, манера жестикуляции и т. п. В рамках данной статьи будут рассмотрены атрибутивные признаки кочующих женских и мужских персонажей.

К группе женских образов-характеров относятся сценические амплуа галантных дам аристократического происхождения и молоденьких кокетливых служанок.

Галантная дама - обобщённый «кочующий» оперный образ, вобравший в себя прежде всего сословные атрибутивные признаки, подтверждающие принадлежность к аристократическому кругу. В операх Моцарта в качестве галантных дам выступают, к примеру, графиня Розина («Свадьба Фигаро»), Донна Анна и Донна Эльвира («Дон Жуан»), Констанца («Похищение из Сераля») и другие. Отличительной особенностью сценического поведения оперно-театральных галантных дам является изысканная вежливость и чрезвычайная обходительность в общении, 
витиеватость и замысловатость речевых оборотов в манере говорить, изящность силуэта и грациозность жестикуляции, подчёркиваемая в пластике.

Наиболее ярко атрибутивные признаки галантной дамы представлены в медленных частях моцартовских сонат К. 309, К. 457, К. 545, К. 576, а также в нескольких медленных разделах финала сонаты К. 284.

Инвариантами атрибутивной лексики грациозной и кокетливой галантной дамы в театральных клавирных сонатах Моцарта стали интонации фигуры пластического и речевой этимологии происхождения с закреплёнными значениями, присутствующие в медленных и умеренно-медленных частях клавирных сонат.

Изящная пластика и витиеватая грациозная жестикуляция галантной дамы в клавирных текстах сонат Моцарта атрибутируется с помощью интонаций «приседания» (т. 4, 8 примера № 2), «галантных» фигур (т. 2, 4 примера № 1) и т. д. Интересно, что интонация «приседания» в высказываниях героини часто формируется в контексте ритмоинтонационной фигуры «предъёма» и служит средством выражения галантного учтивого женского реверанса.

К числу речевых акустических признаков героини, свойственных светской «façon de parler», относятся «клише колоратуры» (т. 7 примера № 1), генетически связанные с развёрнутыми оперными виртуозными колоратурными пассажами. Интересно, что нередко в интонационной лексике высказываний галантной дамы встречаются повелительные и сигнальные интонации в прямом значении (т. 7 примера № 1; т. 1 примера № 2). Однако контекстуальные условия - медленный темп, танцевальная природа музыкального изложения - «нивелируют» первичное значение этих смысловых структур и атрибутируют внешне степенный благородный женский образ-характер, содержащий также черты настойчивости и упорства.
При этом за внешним проявлением спокойствия и выдержанности в темпераменте образа-характера галантной дамы нередко ощущаются элементы экспрессивности, взволнованности и трепетности её натуры. Такая эмоциональная двойственность театрального амплуа свидетельствует о наличии компонентов «внешнего» и «внутреннего» действия героини. «Внутреннее» - эмоциональное состояние галантной дамы в клавирных сонатах Моцарта часто атрибутируется выступающими в качестве смысловой структуры «альбертиевыми» басами (примеры № 1; 2). Представленные атрибутивные признаки образа-характера галантной дамы при всей сдержанности и аристократизме манер подчёркивают нечуждую ей кокетливость и игривость.

Сценическое амплуа образа-характера служанки (субретки, горничной) весьма специфичен и, как правило, неоднозначен в своём проявлении в различных ситуациях сюжетного действия. С одной стороны, темперамент служанки импульсивный, энергичный, и характер её предприимчивый. Речь служанки грубовата и прямолинейна, тороплива и сбивчива, нередко насыщена повторами слов, фраз, междометиями и резкими выкриками. Пластика и жестикуляция амплуа служанки, как правило, не лишены изящества и грации, но их отличает подвижность, поспешность и суетливость. С другой стороны, типичным для театрального амплуа такого рода является подражание модели поведения знатной дамы, включающей грациозные движения и особую манеру речевого общения. Такой многоплановостью обладают, к примеру, образы-характеры Сюзанны («Свадьба Фигаро»), Блондхен («Похищение из сераля»), Деспины («Так поступают все женщины»), Церлины («Дон Жуан») (примеры № 4; 5).

«Кочующий» театральный образ-характер служанки, в отличие от амплуа аристократической дамы, представляется менее статичным, что несомненно, 
сказалось и на процессе его атрибутации в клавирных текстах. Так, часто в музыкальном воплощении служанки могут содержаться смысловые структуры пластического происхождения, зародившиеся в светских танцах («галантные» фигуры, интонации «приседания», «женский реверанс» и т. д.). Обнаружить в клавирном тексте признаки присутствия именно служанки возможно по совокупности интонационно-лексических стереотипов, не свойственных атрибутивным признакам амплуа галантной дамы.

Атрибутивные признаки образа-характера молоденькой кокетливой служанки обнаруживаются в текстах первых частей клавирных сонат Моцарта К. 279, К. 311, К. 545, а также в финале сонаты К. 281.

Как показали наблюдения, акустический эквивалент «façon de parler» служанки в музыкальных текстах сонат Моцарта атрибутируется посредством интонационных клише «итальянской скороговорки» (т. 2-3 примера № 6), обилия «тират» (т. 6-9 примера № 6), резких «выкриков» (т. 1, 3 примера № 6) и импульсивных «междометий (т. 10-13 примера № 6).

Идентификационными двигательно-пластическими атрибутами образа-характера типичной кокетливой простушки-субретки в текстах клавирных сонат Моцарта стали интонации «бега» (т. 1, 3 примера № 6), «кружения», фигуры «поклона» (т. 4 примера № 7), в быстрых темпах создающие комический эффект. Кроме того, изображённые в клавирных текстах высказывания служанки нередко сопровождаются интонационно-лексическими стереотипами народного музицирования - «пастушеской свирели» - знаками-образами сельской пасторальной лирики, свидетельствующими о присутствии в содержании музыкального текста героев из крестьянской среды (т. 1-2, 4-5 примера № 7). В этом прослеживается генетическая связь атрибуции образа-характера в клавирном тексте с музыкальным воплощением типичных оперных служанок.
В музыкальных текстах клавирных сонат Моцарта обнаруживаются кочующие оперно-театральные амплуа мужских героев. Подобно женским образам-характерам, они также предстают в двух противоположных социальных ипостасях - галантные кавалеры аристократического происхождения и молодые слуги. В сюжетах оперных произведений Моцарта к числу пары антагонистических мужских персонажей можно отнести, например, Графа Альмавиву и Фигаро («Свадьба Фигаро»), Бельмонта и Педрильо («Похищение из Сераля»), Дона Жуана и Лепорелло («Дон Жуан») и так далее.

В текстах клавирных сонат Моцарта данная пара мужских героев атрибутируется, главным образом, посредством типичных акустических эквивалентов «façon de parler» и смысловых структур двигательно-пластического происхождения.

«Кочующий» образ-характер галантного кавалера представляет собой обобщённое оперно-театральное амплуа изысканного учтивого аристократа, оказывающего знаки внимания галантной даме или служанке. В сюжетах оперных произведений Моцарта обнаруживаются два наиболее распространённых типа галантных кавалеров - это, в первую очередь, образ-характер знатного учтивого поклонника-обольстителя, либо богатого ворчливого повесы-опекуна.

В качестве обходительного галантного кавалера в операх Моцарта выступают, например, Феррандо и Гульельмо из оперы «Так поступают все женщины», Граф Альмавива из оперы «Свадьба Фигаро», Дон Фракассо из оперы «Притворная простушка и другие. В амурных сценах их речевые высказывания отличаются особой утончённостью и исключительной любезностью. Движения галантных кавалеров полны доблести и мужественности (пример № 8).

В первых частях клавирных текстах сонат Моцарта К. 309, К. 457, К. 570 и К. 576, 
а также во второй части сонаты К. 331 и в финале сонаты К. 309 образ-характер учтивого галантного кавалера, как правило, атрибутируется при помощи клише смысловых структур эмотивно-речевого происхождения - интонационного стереотипа колоратуры, интонаций «восклицания», "утверждения», «патетических возгласов", а также смысловых сегментов двигательно-пластической этимологии - фигур «героического жеста», «галантных фигур», различных «этикетных формул баса» и так далее (т. 1-2 примера № 9). Кроме того, к атрибутивным признакам присутствия в клавирном тексте учтивого галантного кавалера относятся сигнальные интонации: фанфары, роговые сигналы (т. 1-2 примера № 10).

Иной «кочующий» образ-характер знатного кавалера являет собой амплуа брюзгливого опекуна преклонных лет, увивающегося за молоденькими кокетками. В операх Моцарта в таком амплуа представлены, например, Дон Альфонсо («Так поступают все женщины»), доктор Бартоло («Свадьба Фигаро»), Джервазио («Обманутый жених»), Дон Кассадро («Притворная простушка») и другие. В оперных «сценах-ухаживания" данные комические персонажи предстают, как правило, в качестве ворчливых пожилых повес. Речь их часто тороплива и сумбурна, движения и жестикуляция отличаются сбивчивостью и неуклюжестью (пример № 11).

Пример музыкального воплощения встречается в клавирном тексте первой части сонаты Моцарта К. 283 (Allegro). Образ-характер брюзгливого старика атрибутируется преимущественно акустическим эквивалентом речевых комических интонаций «ворчания», развивающихся внутри развёрнутого смыслового сегмента - стереотипа «итальянской скороговорки (т. 5-11 примера № 12).

«Кочующий» образ-характер слуги представляет собой амплуа активного, услужливого и предприимчивого весельчака. В моцартовских операх в роли слуг выступают такие персонажи, как Фигаро («Свадьба Фигаро»), Лепорелло («Дон Жуан»), Педрильо («Похищение из сераля»), Нардо («Мнимая садовница») и другие.

Амплуа слуги во многом схоже с образом-характером служанки: в нём также, в зависимости от сценической ситуации, нередко парадоксально перемежаются признаки двух противоположных социальных сфер. Высказывания слуги, в соответствии с развитием сюжетной канвы, могут быть полны беззаботной легкомысленности. В иных сценических ситуациях речь героя нередко содержит настойчивые, запальчивые и даже дерзкие интонации. Движения и жестикуляция слуги, как правило, лишены галантности и изысканности персонажа (исключения нередко составляю амурные сцены). Они часто сочетаются с пластическими элементами народных танцев - «притоптываниями», «прыжками» (пример № 13).

Атрибутивные признаки присутствия образа-характера слуги обнаруживаются в первой части клавирной сонаты Моцарта К. 457, а также музыкальных текстах финалов сонат К. 279, К. 284, К. 311, К. 545, К. 570.

В музыкальном тексте сонаты К. 545 (Allegretto) атрибутирование героя сфокусировано, главным образом, вокруг развития ритмоинтонационной танцевальной фигуры «притопывания» (т. 1-2, 5-6 примера № 14), представленного в виде ленточного терцового двухголосия знака-образа сельской лирики. Кроме того, пластическим атрибутом движений слуги в тексте финала стал вариант формулы "салюта и поклона кавалера", помещённого в контекст быстрого темпа и создающего комический эффект (т. 7-8 примера № 14). При этом, к числу атрибутивных признаков героя в данном случае относятся также встречающееся в высказывании слуги интонационное клише «итальянской скороговорки» - знак-образ «простонародной речи» (т. 2-4, 6-8 
примера № 14). В целом, обнаруженные в финале сонаты атрибутивные признаки призваны воплотить образ-характер беспечного балагура и весельчака.

Итак, как показали семантические наблюдения, в музыкальных текстах сонат Моцарта часто обнаруживаются атрибутивные признаки обобщённых оперно-театральных пар социально про- тивоположных женских и мужских образов-характеров. В клавирных текстах моцартовских сонат процесс их атрибутирования осуществляется посредством совокупности специфических интонационно-лексических и акустических эквивалентов, соответствующих эмотивно-речевым и двигательно-пластическим манерам «кочующих» амплуа героев.

\section{थ ПРИМЕЧАНИЯ}

1 Литературоведческий термин, введённый в музыкознание в работах P.М. Байкиевой (см.: [1; 2]).

2 Façon de parler - (от франц.) манера выражаться, говорить, высказываться, присущая определённой категории персонажей в произведении.
3 Кроме того, согласно сценической ситуации нередко знатная Дама вынуждена выступать в роли Служанки. По такому принципу, например, происходит развитие образов-характеров Розины («Притворная простушка»), Сандрины («Мнимая садовница») и т. д.

\section{थ НОТНЫЕ ПРИМЕРЫ}

Пример № 1

B.A. Моцарт. Опера «Свадьба Фигаро».

I действие. № 10. Каватина Графини
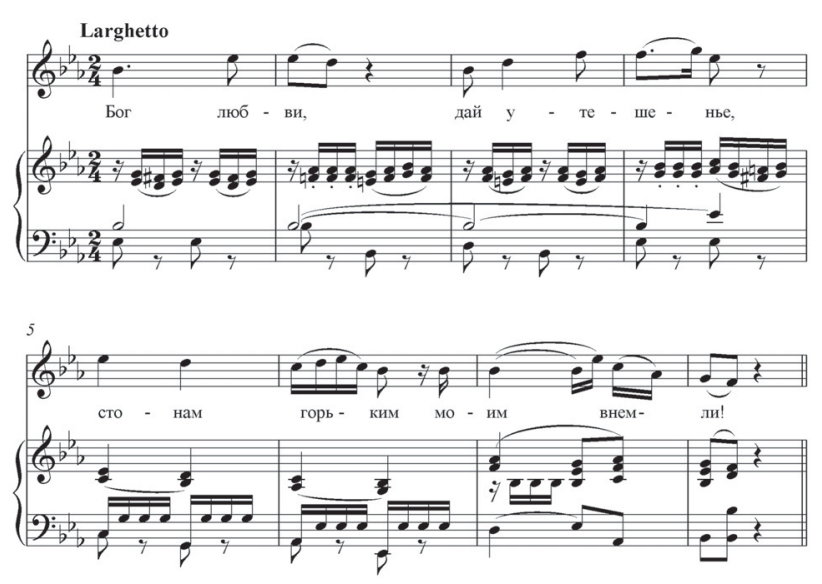

Пример № 2

Соната К. 545, II часть
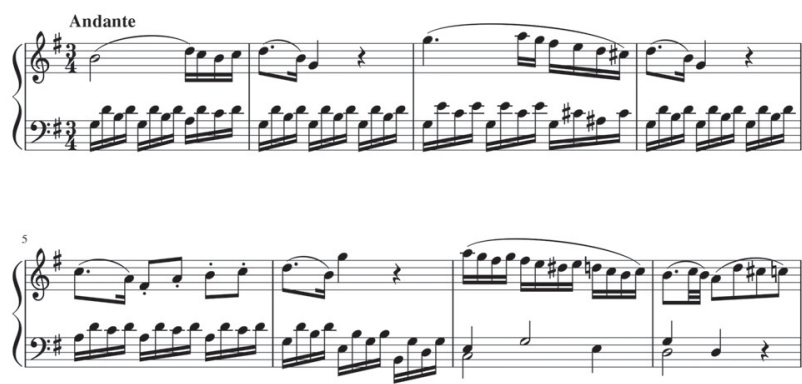
Пример № 3

Соната К. 284, III часть, тема вариащий

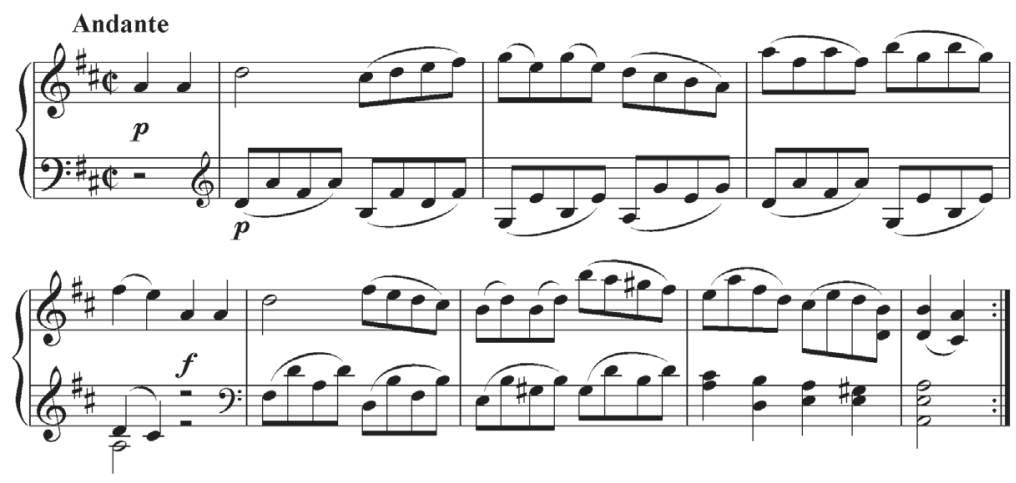

Пример № 4

Опера «Так поступают все женщины"».

I действие, картина 3. № 12 Ария Деспины
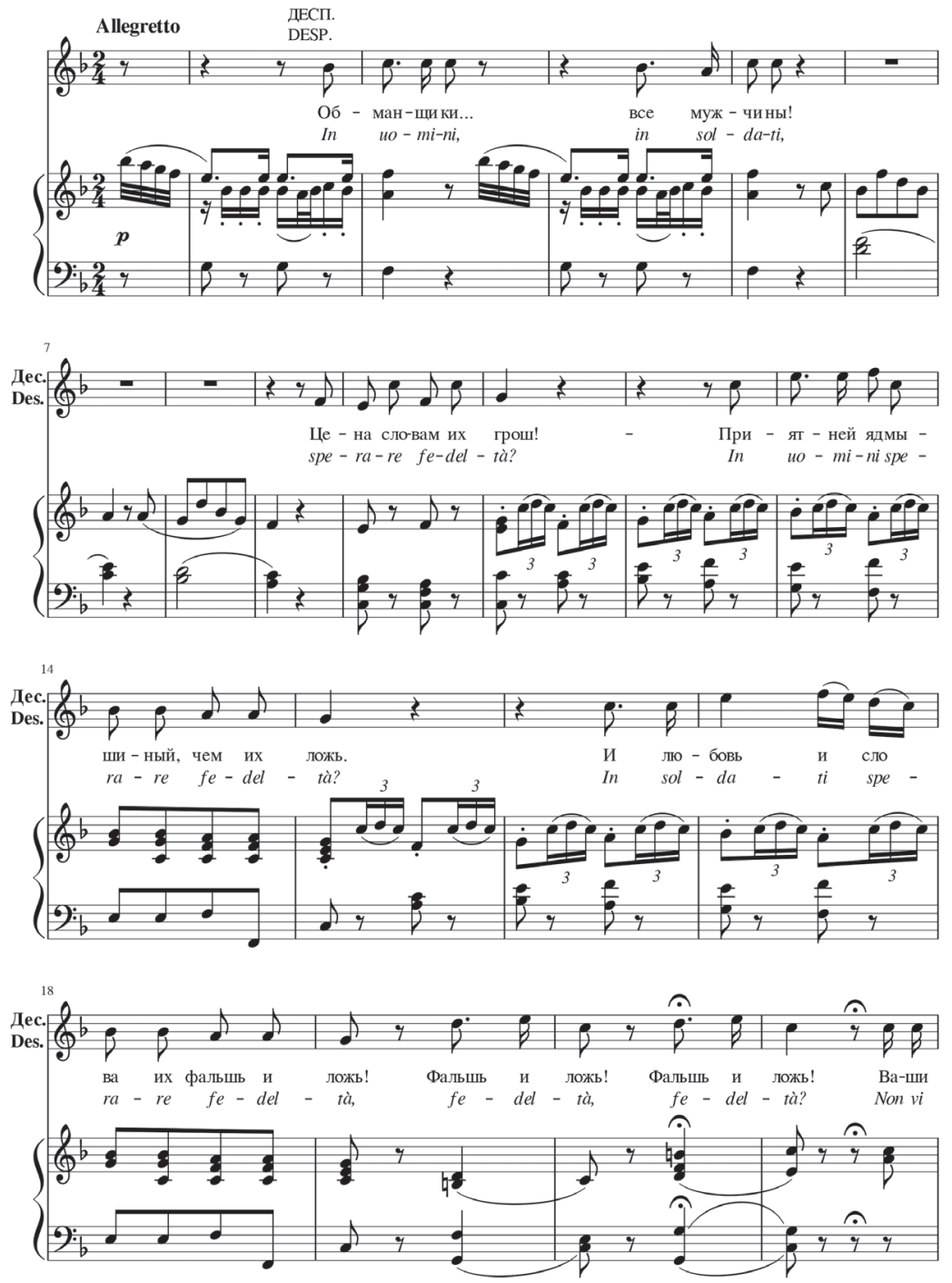
Пример № 5

Опера “Дон Жуан». II действие. № 19

Ария Церлины
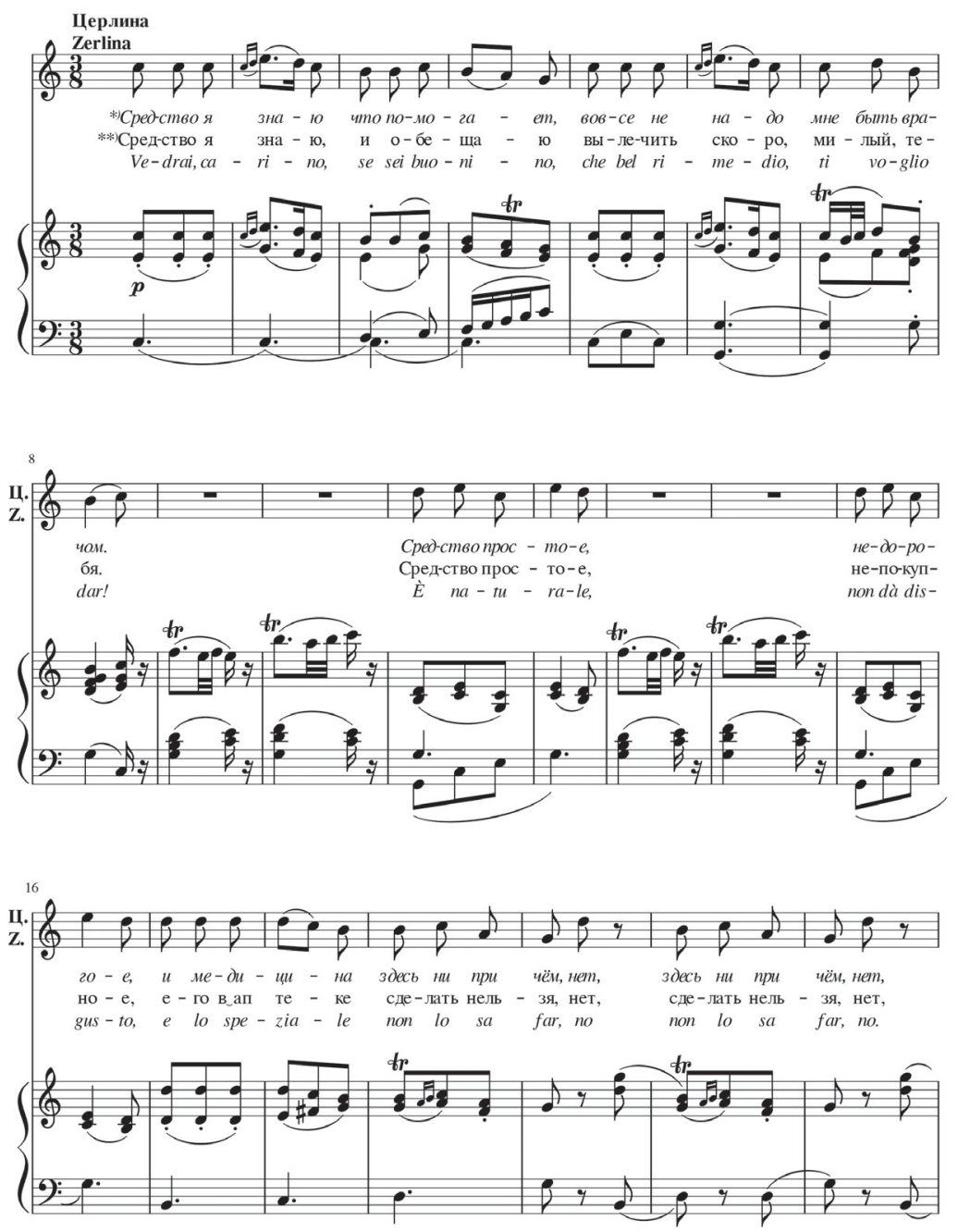

Пример № 6

Соната К. 279, I часть
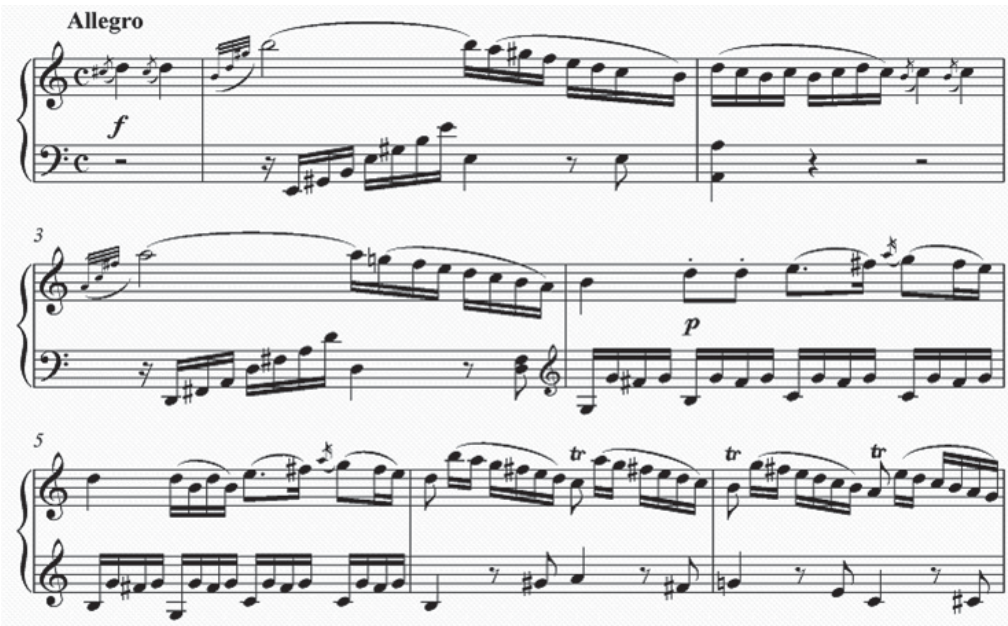
Пример № 7

Соната К. 311, I часть
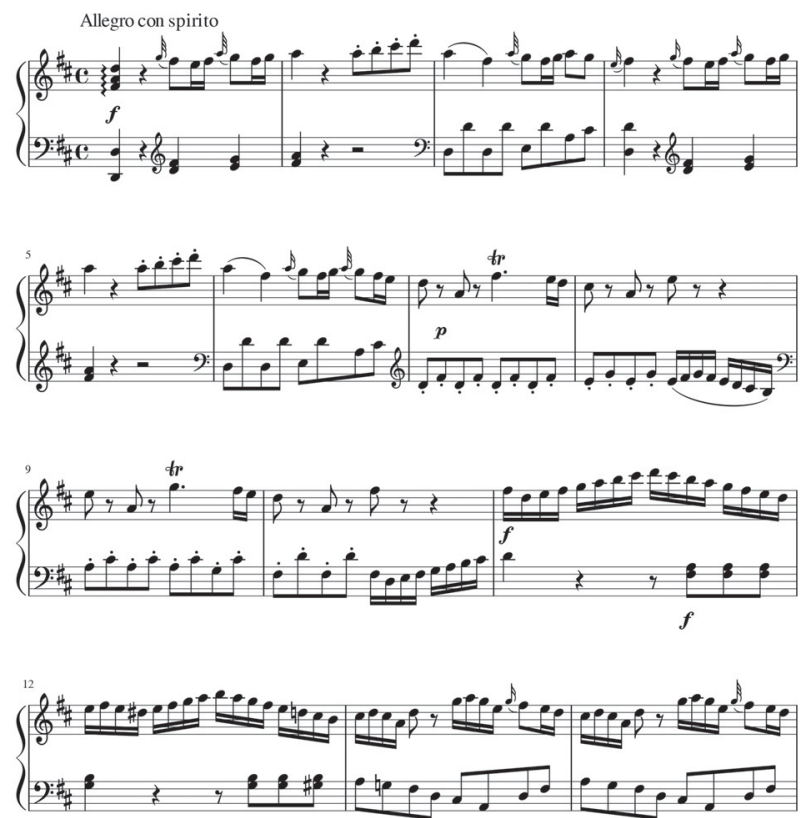

Пример № 8

Опера «Так поступают все женщины».

I действие, картина 4.

№ 17 Ария Феррандо
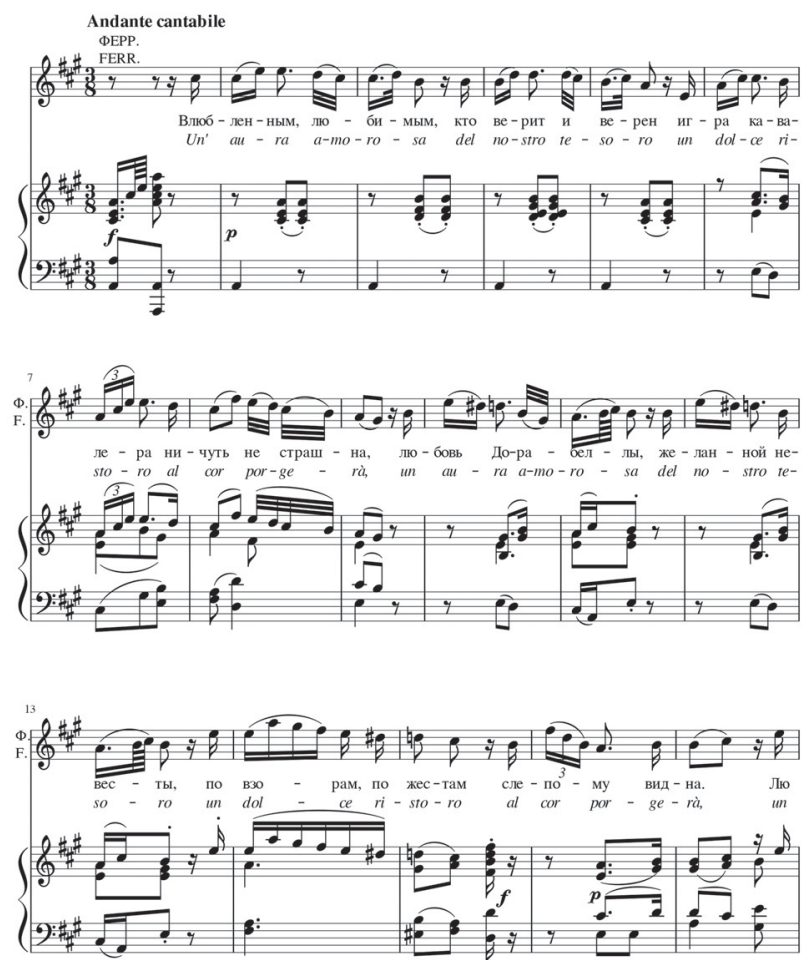

Пример № 9

Соната К. 309. I часть

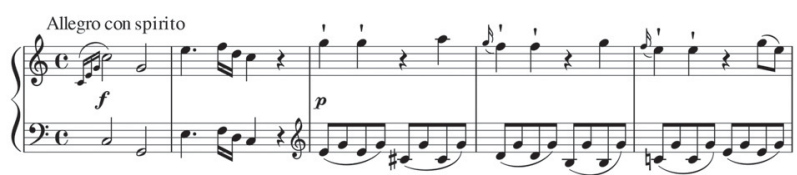

Пример № 10

Соната К. 457. I часть

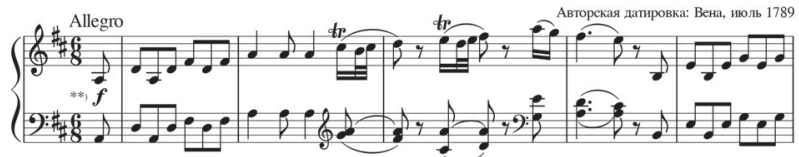

\section{Пример № 11}

Опера «Так поступают все женщины».

I действие, картина 2.

№ 5 Ария Дона Альфонсо
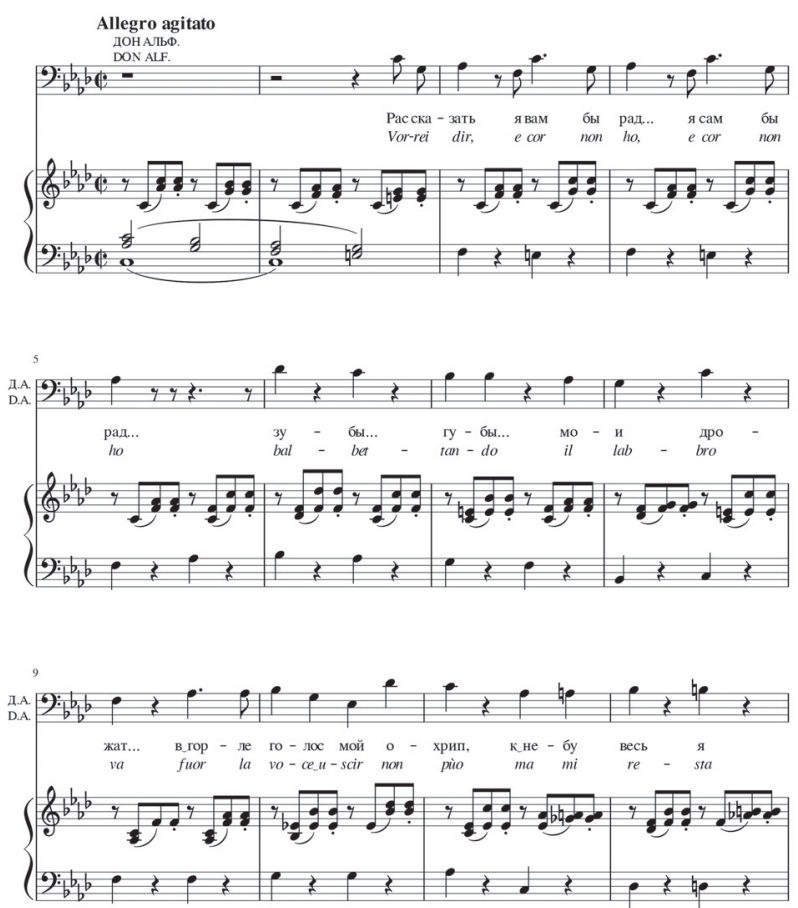
Пример № 12

Соната К. 283. I часть
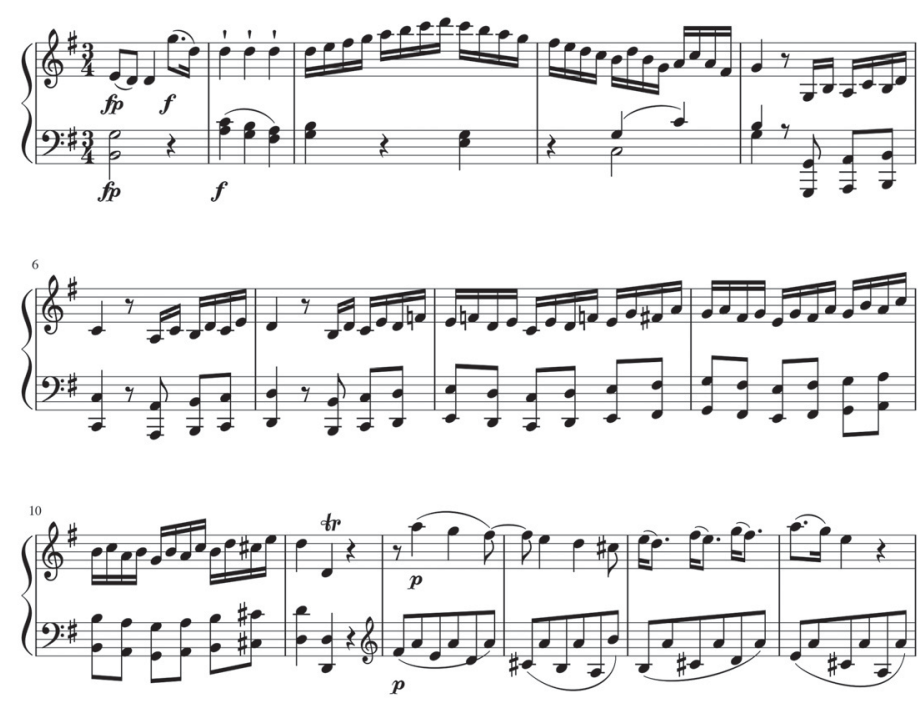

Пример № 13

Опера «Свадъба Фигаро». I действие. № 9

Ария Фигаро
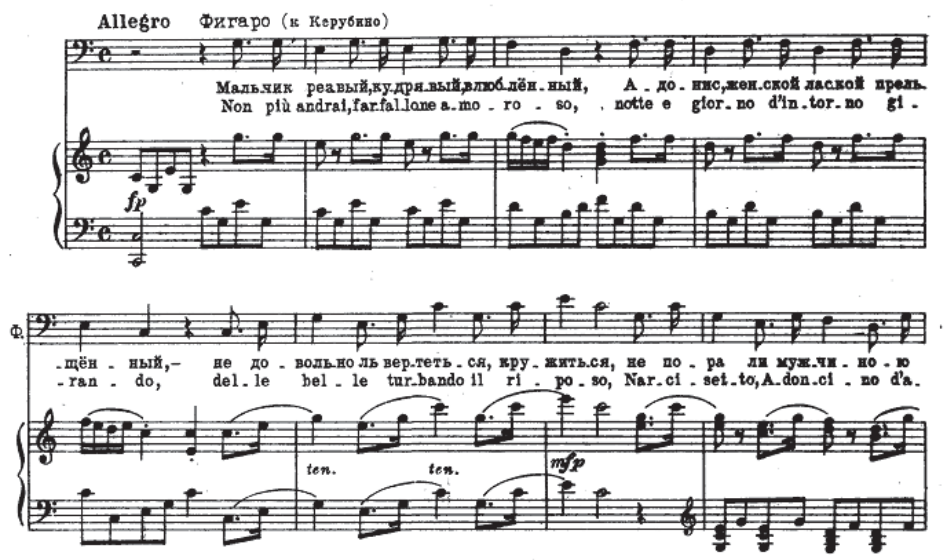

Пример № 14

Соната К. 545. III часть
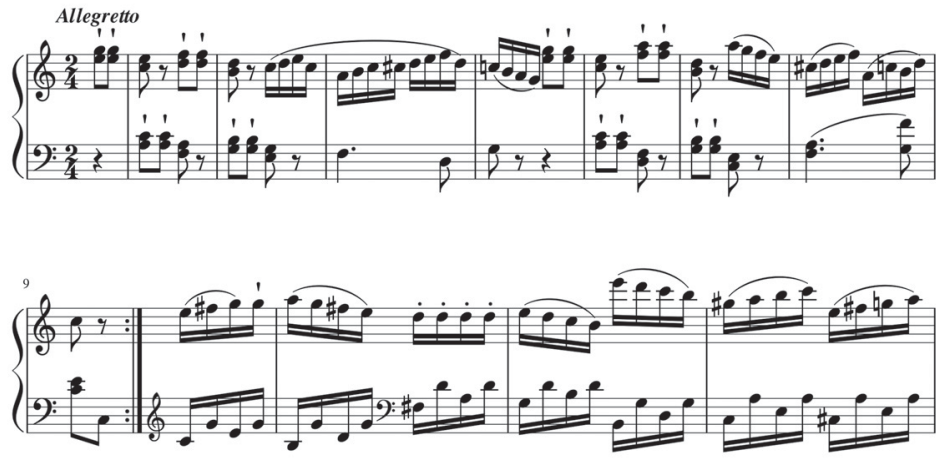


\section{थ лиТЕРАТУРА $\sim$}

1. Байкиева Р.М. Герой как категория музыкальной поэтики и его признаки в музыкальном тексте пьес детского фортепианного репертуара // Музыка прошлого и современность: сб. ст. / отв. ред.-сост. Л.Н. Шаймухаметова. Уфа: Лаборатория музыкальной семантики УГАИ, 2010. С. 5-13.

2. Байкиева P.М. К разработке категории героя в музыкальном тексте пьес детского фортепианного репертуара // Проблемы музыкальной науки. 2011. № 2. С. 229-233.

3. Чигарёва Е.И. Оперы Моцарта в контексте культуры его времени: Художественная индивидуальность. Семантика. Изд. 3-е, испр. и доп. М.: ЛИБРОКОМ, 2009. 280 с.

4. Шаймухаметова Л.Н., Кириченко П.В. «Театральный диалог» в классической музыкальной теме // Музыкальный текст и исполнитель / отв. ред.-сост.

Л.Н. Шаймухаметова. Уфа: Лаборатория музыкальной семантики УГАИ, 2004. С. 17-38.

\section{Об авторе:}

Данилова Яна Юрьевна, научный сотрудник,

Уфимский государственный институт искусств имени Загира Исмагилова, Лаборатория музыкальной семантики (450008, г. Уфа, Россия), lab234nt@yandex.ru

\section{e REFERENCES}

1. Baykieva R.M. Geroy kak kategoriya muzykal'noy poetiki i ego priznaki v muzykal'nom tekste p'es detskogo fortepiannogo repertuara [Hero as a Category of Musical Poetics and Its Signs in the Musical Text of Pieces of Children's Piano Repertoire]. Muzyka proshlogo i sovremennost': $s b$. st. [Music of the Past and Modernity: Collection of Articles]. Comp. by L.N. Shaymukhametova. Ufa: Laboratory of Musical Semantics Ufa State Academy's of Arts. 2010, pp. 5-13.

2. Baykieva R.M. K razrabotke kategorii geroya v muzykal'nom tekste p'es detskogo fortepiannogo repertuara [To the Development of the Category of the Hero in the Musical Text of the Pieces for Children]. Problemy muzykal'noj nauki / Music Scholarship. 2011. No. 2 pp. 229-233.

3. Chigareva E.I. Opery Motsarta v kontekste kul'tury ego vremeni: Khudozhestvennaya individual'nost'. Semantika [Mozart's Operas in the Context of the Culture of His Time: Artistic Individuality. Semantics]. 3rd ed., corrected and expanded. Moscow: LIBROKOM, 2009. 280 p.

4. Shaymukhametova L.N., Kirichenko P.V. «Teatral'nyy dialog» v klassicheskoy muzykal'noy teme ["Theatrical dialogue" in the Classical Musical Theme]. Muzykal'nyy tekst i ispolnitel' [Musical Text and its Performer]. Comp. by L.N. Shaymukhametova. Ufa: Laboratory of Musical Semantics Ufa State Academy's of Arts. 2004, pp. 17-38.

\section{About the author:}

Yana Yu. Danilova, Research Associate, Ufa State Institute of Arts named after Zagir Ismagilov, Laboratory of Musical Semantics (450008, Ufa, Russia), lab234nt@yandex.ru

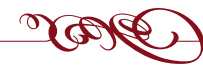

